\title{
Faktor-Faktor yang Berpengaruh terhadap Adverse Drug Reaction pada Penggunaan Obat Anti Tuberkulosis
}

\section{Factors that Influence Adverse Drug Reaction in the Use of Antituberculosis Medicines}

\author{
Lucia Vita Inandha Dewi ${ }^{1}$, Lukman Hakim² ${ }^{2}$ Sismindari²,Ngatidjan² \\ ${ }^{1}$ Universitas Setia Budi Surakarta \\ 2Universitas Gadjah Mada Yogyakarta \\ Email: lucia.vita@yahoo.com
}

(tanggal diterima: 05-08-2020 , tanggal disetujui: 21-10-2020)

\section{INTISARI}

Adverse Drug Reaction (ADR) pada pengobatan tuberkulosis dapat menurunkan kualitas hidup maupun kepatuhan pengobatan pasien. Pengobatan jangka panjang memiliki risiko timbulnya ADR. untuk mencegah ADR yang berbahaya perlu dilakukan monitoring dengan baik, faktor-faktor prediktor yang mempengaruhi ADR perlu diketahui sebagai upaya mencegah kejadian ADR.

Penelitian ini merupakan penelitian cross sectional yang dilakukan pada pasien tuberkulosis paru di Pusat Kesehatan Masyarakat (PKM) Kabupaten "X"di Yogyakarta, kriteria inklusi adalah pasien yang mendapat obat tuberkulosis kombinasi dosis tetap (KDT) kategori 1, dan usia >17 tahun. monitoring ADR dilakukan sejak bulan ke-dua pengobatan hingga bulan ke- 6 dengan metode wawancara yang dilakukan ketika pasien kontrol ke PKM atau komunikasi menggunakan alat telekomunikasi selular. Analisis hasil dilakukan dengan uji multivariate regresi multinomial.

Hasil penelitian dari 60 responden menunjukkan bahwa berdasar faktor usia kejadian ADR terjadi pada kelompok usia tua , menengah, dan muda dengan persentase $30 \%, 23 \%$, dan 1,6\% tidak ada pengaruh signifikan antara usia terhadap ADR. Berdasar jenis kelamin, ADR terjadi pada lakilaki dan perempuan dengan persentase $40 \%$ dan $15 \%$, tidak ada pengaruh antara jenis kelamin terhadap ADR. Berdasar Indeks Masa tubuh, ADR terjadi pada kelompok IMT rendah, normal, dan lebih dengan persentase $41 \%, 10 \%$,dan $3 \%$ terdapat pengaruh antara IMT dengan kejadian ADR, $p$ value $0,01<0.05 \mathrm{OR}=7,650(2,350-24,898) \mathrm{CI}=95 \%$. Berdasar kelompok $\mathrm{BTA}$, ADR terjadi pada kelompok BTA positif dan negatif dengan persentase $38 \%$ dan $16 \%$, tidak ada pengaruh antara BTA dengan kejadian ADR, berdasar hasil penelitian ini maka perlu dilakukan monitoring ADR terutama pada pasien dengan status nutrisi rendah.

Kata kunci : Adverse Drug Reaction, Tuberkulosis, Kombinasi Dosis Tetap-Obat Antituberkulosis (KDT)

\section{ABSTRACT}

Adverse Drug Reaction (ADR) in tuberculosis treatment can reduce the quality of life and patient adherence to treatment. Long-term treatment carries a risk of developing ADR. To prevent dangerous ADR, it is necessary to monitor properly, predictors that affect ADR are important to be investigated to prevent ADR events.

This study is a cross-sectional study conducted on pulmonary tuberculosis patients at the "X" District Public Health Center (PKM) in Yogyakarta, the inclusion criteria were patients who received fixed-dose combination tuberculosis (KDT) category 1 , age $>17$ years, ADR monitoring. It was carried out from the second month of treatment to the 6th month using the interview method that was carried out when the control patient went to PKM or communicated using a cellular telecommunications device. The results analysis was performed using the multivariate multinomial regression test. 
The results of the research of 60 respondents showed that based on the age factor, the incidence of ADR occurred in the old, middle, and young age groups with a percentage of $30 \%, 23 \%$, and $1.6 \%$, there was no significant effect between age on ADR. Based on gender, ADR occurred in men and women with a percentage of $40 \%$ and $15 \%$, there was no effect between sexes on ADR. Based on the body mass index, ADR occurred in the low, normal, and over BMI group with a percentage of $41 \%, 10 \%$, and $3 \%$, there was an influence between BMI and the incidence of ADR, $p$ value $0.01<0.05 \mathrm{OR}=7,650(2,350-24,898) \mathrm{CI}=95 \%$. Based on the results of this study it is necessary to monitor ADR, especially in patients with low nutritional status.

Key words : Adverse Drug Reaction, Tuberculosis, Fixed-dosed combination-Antituberculosis Drug (FDC)

\section{PENDAHULUAN}

Penyakit tuberkulosis hingga saat ini berada diantara 10 tertinggi penyebab kematian di dunia(1). Negara Afrika, India, China dan Indonesia merupakan Negara dengan kasus tuberkulosis tertinggi di dunia. Angka kejadian tuberkulosis di Indonesia menurut WHO pada tahun 2016 dilaporkan sebanyak 360.565 kasus dengan angka kesembuhan sebesar 85\% sedangkan pada tahun 2018 kasus yang tercatat sebanyak 563.879 kasus, terdiri dari kasus baru dan kambuh dengan angka kesembuhan sebesar $85 \%$ (2)

Respon berbahaya dan tidak diharapkan dari suatu obat yang terjadi pada dosis lazim disebut sebagai Adverse Drug Reaction (ADR)(3), menurut sebuah penelitian ADR bisa mempengaruhi kualitas hidup pasien(4)

Adverse Drug Reaction (ADR) merupakan hal yang umum terjadi pada seseorang dengan terapi obat, dari sebuah penelitian disebutkan bahwa $30 \%$ pasien yang sedang menjalani pengobatan tuberkulosis dengan regimen standart isoniazid, rifampisin, pirazinamid dan etambutol mengalami ADR bersifat mayor dengan insidensi 7,3 kasus per 100 orang (3), penelitian lain menyebutkan 56 dari 100 subyek dapat mengalami lebih dari satu macam ADR selama pengobatan(6), ADR yang terjadi dapat berupa gangguan gastrointestinal, hepatotoksisitas, dermatologi, dan gangguan neurologi, kejadian hepatotoksisitas, neurologi dan dermatitis yang bersifat mayor dapat menyebabkan dihentikanya pengobatan, baik sebagian ataupun seluruh obat OAT yang terdiri dari Isoniazid, Rifampisin, Pirazinamid, dan Etambutol (7). Faktor usia merupakan faktor yang diduga paling mempengaruhi risiko terjadinya ADR disamping riwayat kesehatan, penggunaan alkohol, maupun kadar albumin (6)(7)(8), adanya prediktor terhadap ADR tentunya akan membantu proses monitoring terhadap ADR tersebut, beberapa faktor yang kemungkinan berpengaruh terhadap kejadian ADR adalah usia, jenis kelamin, indeks masa tubuh, serta BTA.

\section{METODE PENELITIAN}

\section{1. ALAT DAN BAHAN}

Alat penelitian adalah lembar catatan pengobatan, form wawancara ADR, form rekapitulasi data, lembar inform consent, lembar kesediaan menjadi subyek penelitian, software IBM SPSS 17. 


\section{2. CARA KERJA}

Studi ini mendapatkan approval etical clearens dari Komite Etik Fakultas Kedokteran Universitas Gadjah Mada Yogyakarta dengan nomor KE/FK/1334/EC/2015. Sebanyak 60 subyek yang memenuhi kriteria inklusi usia diatas 17 tahun, mendapat pengobatan Obat Anti Tuberkulosis-Kombinasi Dosis Tetap (OAT-KDT) kategori 1, tidak sedang menjalani pengobatan untuk diagnosa selain tuberkulosis, dan tidak sedang meminum obat selain paket OAT-KDT. Keluhan yang mengarah pada reaksi yang tidak diinginkan setelah meminum obat dipantau secara prospektif mulai bulan ke-2 hingga bulan ke-6. Pengambilan data dilakukan di Pusat Kesehatan Masyarakat (PKM) Kabupaten X Yogyakarta pada tahun 2017-2018, Data diperoleh melalui proses wawancara langsung kepada subyek yang telah mendapatkan inform consent dan bersedia mengikuti protokol penelitian. Monitoring dilakukan secara berkala setiap pasien kontrol satu bulan sekali di PKM atau melalui media telekomunikasi. Data yang diperoleh kemudian digolongkan berdasar umur, berat badan, dan jenis kelamin yang diperoleh dari catatan medis. Data berat badan kemudian digunakan untuk menghitung Indeks masa tubuh (IMT). Data yang terkumpul dilakukan analisis univariat dengan cara menghitung persentase kejadian, selanjutnya dilakukan analisis multivariat regresi multinomial untuk mengetahui pengaruh variabel umur, IMT, dan jenis kelamin terhadap variabel dependen berupa terjadinya ADR.

\section{HASIL DAN PEMBAHASAN}

\subsection{Karakteristik Pasien}

Tabel 1. Distribusi Karakteristik Pasien, $n=60$

\begin{tabular}{|c|c|}
\hline Karakteristik & $\mathbf{n}(\%)$ \\
Usia & \\
$17-24$ & $2(3,3)$ \\
$25-45$ & $27(45,0)$ \\
$45-65$ & $31(51,7)$ \\
\hline Jenis kelamin & \\
Laki-laki & $41(68,3)$ \\
perempuan & $19(31,7)$ \\
\hline Indeks Masa Tubuh & $32(53,3)$ \\
\hline Underweight $(<18.5)$ & $23(38,3)$ \\
Normal $(18.6-25.00)$ & $5(8,3)$ \\
\hline Lebih $(>25.00)$ &
\end{tabular}

Tabel 1 menunjukkan bahwa berdasar tingkatan usia, persentase terbanyak responden berada pada usia tua sebesar $51.7 \%$. Usia lanjut merupakan faktor risiko terjadinya Adverese Drug Reacion (ADR) (9) (10), karena itu monitoring ADR pada usia lanjut sangat diperlukan selama pengobatan, selain itu hasil Riset Kesehatan Dasar (Riskesdas) 2013 menyatakan bahwa prevalensi tuberkulosis meningkat dengan semakin tingginya usia(11). Berdasarkan kategori jenis kelamin, responden laki-laki lebih banyak dibandingkan dengan perempuan, hal ini sesuai dengan 
jumlah penderita tuberkulosis di dunia bahwa jumlah pasien laki-laki lebih besar daripada perempuan(12) selain faktor merokok, rendahnya akses perempuan terhadap fasilitas kesehatan diduga menyebabkan temuan kasus pada perempuan lebih sedikit daripada laki-laki (13). Berdasarkan kategori Indeks masa tubuh dapat diamati bahwa 53,3 \% responden memiliki IBM yang rendah, IBM merupakan salah satu parameter yang digunakan untuk melihat status nutrisi pasien, disebutkan bahwa status nutrisi berpengaruh terhadap imunitas pasien yang rendah dan berperan dalam proses terjadinya tuberkulosis ekstraparu(14) maupun tuberkulosis paru (15).

\subsection{Identifikasi ADR}

Keluhan tidak diinginkan responden setelah minum obat dicatat dan dilakukan tahapan analisis naranjo untuk menentukan apakah ADR disebabkan karena obat atau karena sebab lain, berikut ini hasil persentase ADR yang dialami responden :

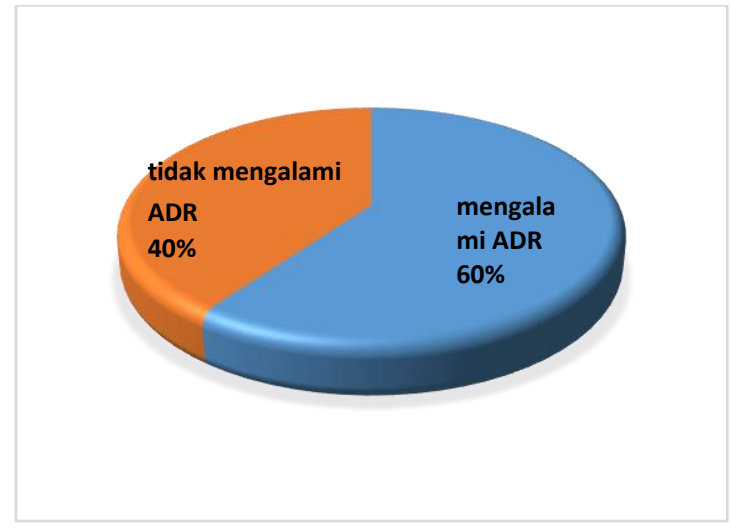

Gambar 1. Persentase kejadian ADR

Gambar 1 menunjukkan bahwa dari 60 responden sebanyak $40 \%$ diantaranya tidak mengalami ADR, dan 60\% mengalami ADR dengan jenis ADR seperti tercantum dalam gambar 2 berikut ini :

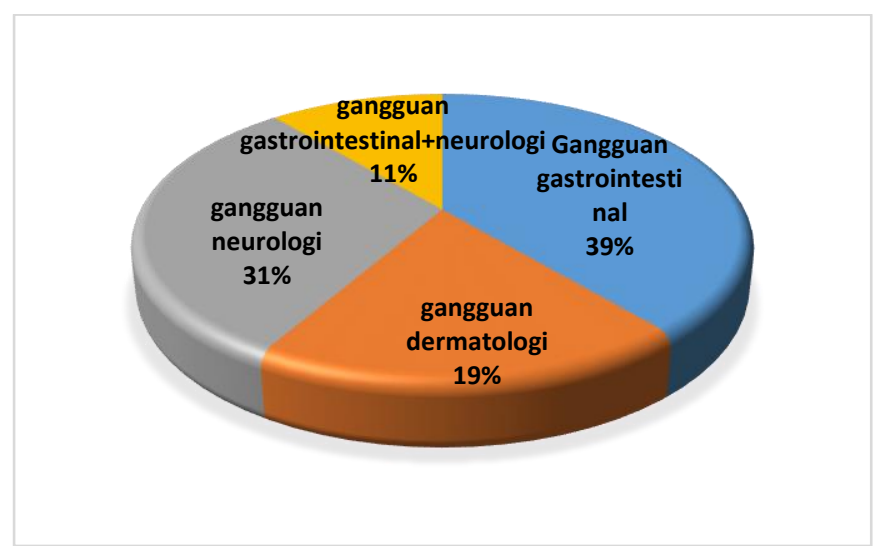

Gambar 2. Persentase jenis ADR 
Gambar 2 menunjukkan jenis ADR berupa gangguan gastrointestinal, dermatologi, neurologi dan campuran antara gangguan gastrointestinal-neurologi dengan persentase sebesar 39\%,19\%,31\%,dan 11\%, yang termasuk dalam definisi gangguan gastrointestinal adalah nausea, vomiting dan nyeri epigastrik, yang tergolong dalam gangguan dermatologi terdiri dari rash dan urtikaria, sedangkan yang tergolong dalam gangguan neurologi berupa nyeri, pusing, numbness, kesemutan, serta gangguan penglihatan. Beberapa penelitian tentang ADR OAT menyebutkan bahwa ADR gastrointestinal merupakan ADR yang umum terjadi pada penggunaan OAT (6), Pada subyek penelitian ini tidak didapat kasus ADR hepatotoksik akibat OAT, namun beberapa literatur menyebutkan bahwa gejala gangguan hepar dapat diawali dengan keluhan berupa gangguan gastrointestinal, pruritis,dan fatique,(16)(17)(18) karena itu adanya keluhan gastrointestinal dan dermatologi harus mendapatkan monitoring dan kewaspadaan terhadap hepatotoksisitas akibat OAT.

Gangguan neurologi dapat terjadi pada pengguanaan OAT, obat yang diduga sebagai penyebab gangguan neurologi adalah isoniazid (20) hal tersebut terjadi karena mekanisme penurunan kadar piridoksin akibat proses inhibisi enzim piridoxin fosfatase oleh metabolit isoniazid (20)

Tabel 2. Pengaruh Variabel terhadap ADR, $n=60$

\begin{tabular}{|c|c|c|c|c|c|}
\hline Karakteristik & n $(\%)$ & $\begin{array}{c}\text { Mengalami } \\
\text { ADR }\end{array}$ & $\begin{array}{c}\text { Tidak mengalami } \\
\text { ADR }\end{array}$ & $p$-value & Odss Ratio $(\mathrm{CI}=95 \%)$ \\
\hline $\begin{array}{c}\text { Usia } \\
17-24 \\
25-45 \\
45-65\end{array}$ & $\begin{array}{c}2(3,3) \\
27(45,0) \\
31(51,7)\end{array}$ & $\begin{array}{c}1(1,6) \\
14(23,3) \\
18(30,0)\end{array}$ & $\begin{array}{c}1(1,6) \\
13(21,6) \\
13(21,6)\end{array}$ & 0,355 & $\begin{array}{c}0,361(0,018-7,358) \\
0,245(0,580-8,457) \\
-\end{array}$ \\
\hline $\begin{array}{c}\text { Jenis kelamin } \\
\text { Laki-laki } \\
\text { perempuan } \\
\end{array}$ & $\begin{array}{l}41(68,3) \\
19(31,7)\end{array}$ & $\begin{array}{l}24(40,0) \\
9(15,0)\end{array}$ & $\begin{array}{l}17(28,3) \\
10(16,6)\end{array}$ & 0,832 & $0,659(0,166-2,619)$ \\
\hline $\begin{array}{c}\text { Indeks Masa Tubuh } \\
\text { kurang }(<18.5) \\
\text { Normal }(18.5-24.99) \\
\text { lebih }(>25.00)\end{array}$ & $\begin{array}{c}32(53,3) \\
23(38,3) \\
5(8,3)\end{array}$ & $\begin{array}{l}25(41,0) \\
6(10,0) \\
2(3,0)\end{array}$ & $\begin{array}{c}7(0,11) \\
17(23,8) \\
3(5,0)\end{array}$ & $0,001^{*}$ & $\begin{array}{c}7,650(2,350-24,898) \\
3,976(0,371-42,62) \\
-\end{array}$ \\
\hline
\end{tabular}

Tabel 2 menjelaskan bahwa pada penelitian ini tidak ada pengaruh signifikan antara usia, dan jenis kelamin, berbeda dengan penelitian terdahulu yang menyebutkan bahwa ADR dapat dipengaruhi oleh faktor usia, dan BTA (9), namun demikian walaupun tidak ada pengaruh signifikan antara usia dengan ADR, dapat diamati bahwa kejadian ADR terbesar terjadi pada 30\% kelompok usia tua (45 hingga 65 tahun), karena itu monitoring ADR pada kelompok usia tersebut perlu ditingkatkan. Faktor usia perlu menjadi perhatian dalam monitoring ADR karena fungsi organ semakin menurun seiring dengan meningkatnya usia, penurunan fungsi ginjal merupakan tahapan yang secara progresif terjadi pada bertambahnya usia, hal ini hal ini tentu berkaitan dengan proses eliminasi obat sehingga $t_{1 / 2}$ eliminasi memanjang dan dapat meningkatkan risiko ADR dan toksisitas(20).

Faktor gender dalam penelitian ini tidak menunjukkan adanya pengaruh signifikan terhadap kejadian ADR, dari tabel 2 dapat diamati bahwa angka kejadian 
pada laki-laki sebesar 40\% dari total subyek, angka ini lebih besar daripada kejadian ADR pada perempuan yaitu sebesar $15 \%$, beberapa studi menyebutkan bahwa perempuan berisiko lebih tinggi mengalami ADR, namun hasil ini masih diperdebatkan karena beberapa penelitian menyebutkan kejadian sebaliknya (22)

Hasil pengamatan terhadap status nutrisi yang didefinisikan sebagai IMT menjelaskan adanya pengaruh yang signifikan antara IMT dengan ADR dengan $p$ value $0,01 \mathrm{OR}=7,650(2,350-24,898) \mathrm{CI}=95 \%$, hal ini menunjukkan subyek dengan IMT rendah berisiko sebesar 7,650 kali untuk mengalami ADR. Sebuah literatur menyebutkan bahwa status gizi(nutrisi) berpengaruh terhadap profil farmakokinetika maupun farmakodinamika yang secara klinis dapat memicu terjadinya ADR(21). Indek Masa Tubuh dapat menggambarkan status nutrisi seseorang, pada keadaan status nutrisi rendah dimungkinkan terjadinya kekurangan kadar albumin di dalam darah sehingga toksisitas obat dapat meningkat, kurang nutrisi memicu turunnya daya tahan tubuh sehingga seseorang menjadi rentan terhadap ADR, selain itu kondisi malnutrisi dapat menyebabkan defisiensi piridoxin dalam darah sehingga risiko ADR neurologi dapat meningkat (20).

\section{KESIMPULAN}

Berdasar faktor usia kejadian ADR dari 60 responden terjadi pada kelompok usia tua, menengah, dan muda dengan persentase 30\%, 23\%, dan 1,6\% tidak ada pengaruh signifikan usia terhadap ADR. Berdasar jenis kelamin, ADR terjadi pada laki-laki dan perempuan dengan persentase $40 \%$ dan $15 \%$, tidak ada pengaruh signifikan antara jenis kelamin terhadap ADR. Berdasar Indeks Masa tubuh, ADR terjadi pada kelompok IMT rendah, normal, dan lebih dengan persentase $41 \%$, $10 \%$,dan 3\% terdapat pengaruh signifikan antara IMT dengan kejadian ADR, $p$ value 0,01<0,05 OR=7,650 (2,350-24,898) $\mathrm{CI}=95 \%$. berdasar hasil penelitian ini maka faktor IMT berpengaruh terhadap terjadinya ADR sehingga perlu dilakukan monitoring ADR terutama pada pasien dengan status nutrisi rendah.

\section{DAFTAR PUSTAKA}

[1]. Chan SL, Chua APG, Aminkeng F, Chee CBE, Jin S, Loh M, et al, 2017, Association and clinical utility of NAT2 in the prediction of isoniazid-induced liver injury in Singaporean patients. Subbian S, editor, PLoS ONE,Oct 16;12(10):e0186200.

[2]. World Health Organization, 2019, WHO guidelines on tuberculosis infection prevention and control, update. [Internet]. 2019 [cited 2020 Jul 4]. Available from: http://www.ncbi.nlm.nih.gov/books/NBK539297/

[3]. World Health Organization, 2002, Safety of Medicines,.pdf [Internet] [cited 2020 Jul 22], Available from: http://archives.who.int/tbs/safety/esd_safety.pdf

[4]. Rolfes L, van Hunsel F, Taxis K, van Puijenbroek E,2016, The Impact of Experiencing Adverse Drug Reactions on the Patient's Quality of Life: A Retrospective CrossSectional Study in the Netherlands. Drug Saf. Aug;39(8):769-76. 
[5]. Marra F, Marra CA, Bruchet N, Richardson K, Moadebi S, Elwood RK, et al, 2007,Adverse drug reactions associated with first-line anti-tuberculosis drug regimens, INT J TUBERC LUNG DIS 11(8):868-875

[6]. Denholm JT, McBryde ES, Eisen DP, Penington JS, Chen C, Street AC, 2014 Adverse effects of isoniazid preventative therapy for latent tuberculosis infection: a prospective cohort study. Drug Healthc Patient Saf. Oct 20;6:145-9.

[7]. Schaberg T, Rebhan K, Lode H, 1996 Risk factors for side-effects of isoniazid, rifampin and pyrazinamide in patients hospitalized for pulmonary tuberculosiS, European Respiratory JournaL, Oct 1;9(10):2026-30.

[8]. Resende LSO, Santos-Neto ET dos, 2015, Risk factors associated with adverse reactions to antituberculosis drugs, J bras pneumol ,Feb;41(1):77-89.

[9]. Wahyono TYM, 2016, Kejadian Efek Samping Obat Anti Tuberkulosis pada Pasien Tuberkulosis, J respir Indo 36(4):9.

[10]. Wulandari N, Andrajati R, Supardi S., 2016, Faktor Risiko Umur Lansia terhadap Kejadian Reaksi Obat yang Tidak Dikehendaki pada Pasien Hipertensi, Diabetes, Dislipidemia di Tiga Puskesmas di Kota Depok. Jurnal Kefarmasian Indonesia. Sep 8;6(1):60-7.

[11]. Infodatin Tuberkulosis, Pusat Data dan Informasi Kementerian Kesehatan- 2018, Kemenkes RI

[12]. Global tuberculosis report, 2019, Organisation mondiale de la santé, World Health Organization

[13]. Rokhmah D.,2013, Gender dan Penyakit Tuberkulosis: Implikasinya Terhadap Akses Layanan Kesehatan Masyarakat Miskin yang Rendah. Kesmas: National Public Health Journal. May 1;7(10):447.

[14]. Rosdiani L, Purbaningsih W, Yunus A. Status Nutrisi Berperan dalam Kejadian Tuberkulosis Ekstraparu pada Anak. 2017;1(1):5.

[15]. Yusuf RN. Hubungan Status Gizi dengan Kejadian TB Paru, 2017, Jurnal Kesehatan Saintiki Meditory:11.

[16]. Yu Y-Y, Tsao S-M, Yang W-T, Huang W-C, Lin C-H, Chen W-W, et al.,2019,Association of Drug Metabolic Enzyme Genetic Polymorphisms and Adverse Drug Reactions in Patients Receiving Rifapentine and Isoniazid Therapy for Latent Tuberculosis. IJERPH,Dec 27;17(1):210.

[17]. Tajiri K, Shimizu Y,2018, Practical guidelines for diagnosis and early management of drug-induced liver injury,WJG.;14(44):6774.

[18]. Teixeira RL de F, Morato RG, Cabello PH, Muniz LMK, Moreira A da SR, Kritski AL, et al.,2011 Genetic polymorphisms of NAT2, CYP2E1 and GST enzymes and the occurrence of antituberculosis drug-induced hepatitis in Brazilian TB patients. Mem Inst Oswaldo Cruz. Sep;106(6):716-24.

[19]. Stettner M, Steinberger D, Hartmann CJ, Pabst T, Konta L, Hartung HP, 2015, Isoniazid-induced polyneuropathy in a tuberculosis patient - implication for individual risk stratification with genotyping? Brain Behav. Aug;5(8):n/a-n/a.

[20]. Mafukidze AT, Calnan M, Furin J.,2015, Peripheral neuropathy in persons with tuberculosis. JClin Tuberc Other Mycobact Dis. Dec 3;2:5-11.

[21]. Ortolani E. Nutritional Status and Drug Therapy in Older Adults. J Gerontol Geriatric Res [Internet]. 2013, [cited 2020 Jul 22];02(02). Available from: https://www.omicsgroup.org/journals/nutritional-status-and-drug-therapy-inolder-adults-2167-7182.1000123.php?aid=15273 
[22]. de Vries ST, Denig P, Ekhart C, Burgers JS, Kleefstra N, Mol PGM, 2019, Sex differences in adverse drug reactions reported to the National Pharmacovigilance Centre in the Netherlands: An explorative observational study. Br J Clin Pharmacol. Jul;85(7):1507-15.

[23]. HUBUNGAN ANTARA STATUS GIZI DENGAN EFEK SAMPING OBAT ANTI TUBERKULOSIS PADA PASIEN DEWASA DI BKPM PATI TAHUN 2011 NASKAH PUBLIKASI - PDF Download Gratis [Internet]. [cited 2020 Aug 26]. Available from: https://docplayer.info/37302493-Hubungan-antara-status-gizi-dengan-efeksamping-obat-anti-tuberkulosis-padapasien-dewasa-di-bkpm-pati-tahun-2011naskah-publikasi.html 